\title{
Serum immunoglobulins IgG, IgM, and IgA in maternal cord blood pairs from infants of normal and low birthweights in Tanzania
}

\author{
E R BOERSMA
}

Department of Child Health, Muhimbili Medical Centre Incorporating the Faculty of Medicine, University of Dar-es-Salaam, Tanzania

SUMMARY Serum total protein, albumin, IgG, IgM, and IgA were determined in cord blood of 54 term infants appropriate-for-gestational-age (AGA), 14 preterm AGA infants, and 21 small-fordates infants, and in their mothers immediately after delivery in Dar-es-Salaam. The mean serum levels of total protein, albumin, and IgG in mothers who delivered a term AGA infant were $6 \cdot 8$ $\mathrm{g} / 100 \mathrm{ml}, 2.9 \mathrm{~g} / 100 \mathrm{ml}$, and $1840 \mathrm{mg} / 100 \mathrm{ml}$ respectively, whereas those from their infants were $6.9 \mathrm{~g} / 100 \mathrm{ml}, 4 \cdot 1 \mathrm{~g} / 100 \mathrm{ml}$, and $1471 \mathrm{mg} / 100 \mathrm{ml}$. The de novo synthesis of IgM and IgA during fetal life seems to be activated at an earlier gestational age than in infants in Western countries; this fact subsequently resulted in a higher detection rate for IgM and IgA in cord blood of term AGA infants. IgG in Tanzanian mothers was generally higher than in corresponding cord blood sera, which is contrary to the finding in Europe.

The incidence of low birthweight $(<2500 \mathrm{~g})$ infants in Tanzania is high (15\%) compared with Western countries $(6-7 \%) .{ }^{1}$ The high incidence of infections in underdeveloped countries has been related to unfavourable conditions for intrauterine growth of the fetus, ${ }^{2}$ although in an industrialised country such a relationship could not be shown. ${ }^{3}$

Although some authors ${ }^{4-7}$ have been unable to show a relationship between malaria during pregnancy and neonatal mortality, the importance of malarial prophylaxis for the prevention of severe maternal anaemia and fetal loss (as reviewed by $\mathrm{Kortman}^{7}$ ) has led to the widespread use of malarial prophylaxis during pregnancy in endemic areas. The question of why a healthy child is usually born despite severe placental malarial infection ${ }^{7}$ remains unresolved.

We wished to learn more about the development of humoral immune status (IgG, IgM, and IgA) during fetal life in relation to the immune status in the mother in an area where socioeconomic and nutritional conditions are very different from those in the West. IgM and IgA, unlike IgG, are synthesised by the fetus, which make them suitable for assessing the development of the humoral immune status of the newborn infant. In the Tanzanian population that we studied the IgG, IgM, and IgA levels were determined in maternal and cord blood of term and preterm appropriate-for-gestational-age (AGA) and small-for-dates (SFD) infants immediately after delivery. These data were compared with results from similar studies in Western countries.

\section{Definitions and abbreviations}

A term AGA infant was an infant born within 38-42 weeks of gestation with birthweight within \pm 1 SD from the mean for that particular gestational age, using the local standards ${ }^{8}$ (Fig. 1).

A preterm AGA infant was an infant born before 37 completed weeks of gestation and with birthweight within \pm 1 SD from the mean for the gestational age, using the same local standards.

An SFD infant was an infant with a birthweight $<10$ th centile for gestational age, using the local standards.

\section{Subjects and methods}

The survey was part of a study on the interaction between malaria and pregnancy carried out between September 1976 and September 1977 at the University Hospital Muhimbili Medical Centre and the Government Maternity Ocean Road Hospital. 
Details of local health facilities, population, socioeconomic and geographical circumstances have been given previously. ${ }^{18}$

Maternal venous blood and cord blood was

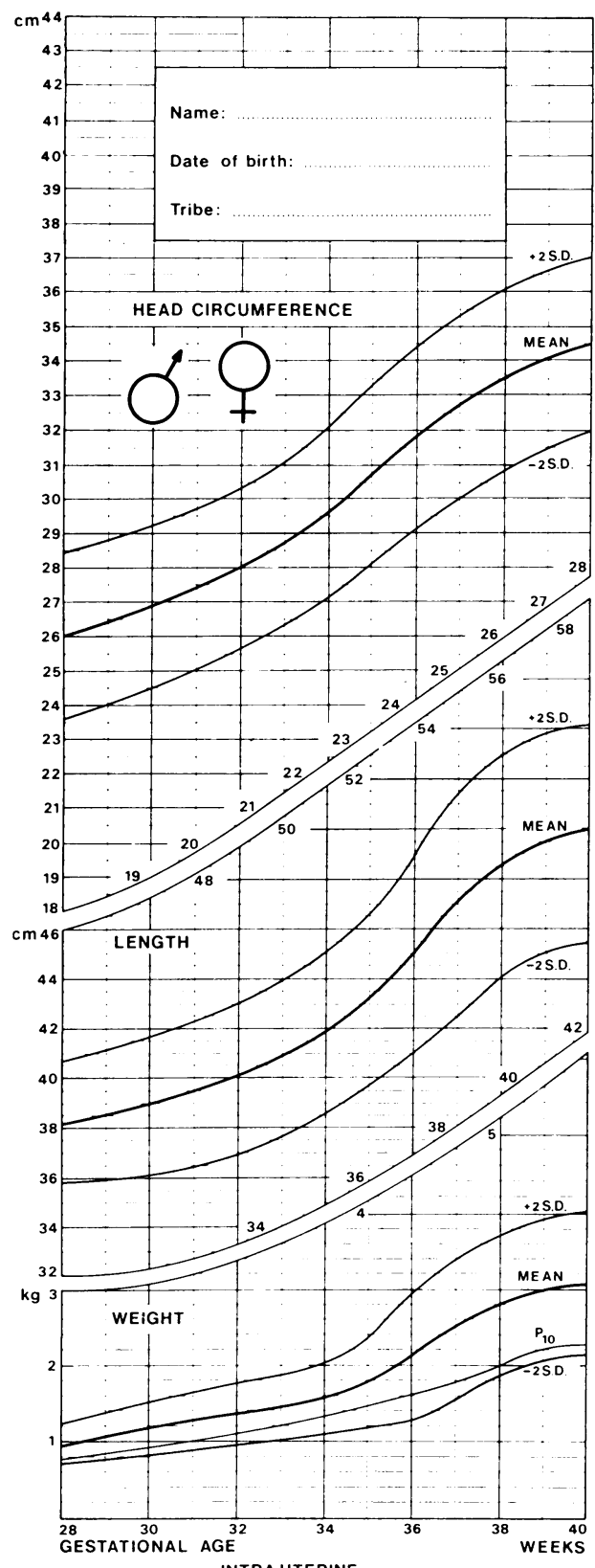

Fig. 1 Intrauterine growth curves for weight, length, and head circumference for Tanzania. ${ }^{8}$ collected from the following groups of mothers and their offspring immediately after delivery:

Group 1. The control group comprised 54 randomly selected mothers and their term AGA infants. The gestational age ranged from 38 to 41 weeks.

Group 2. This group comprised 14 mothers and their preterm AGA infants. The gestational age ranged from 31 to 37 weeks.

Group 3. This group comprised 21 mothers and their SFD infants. The gestational age ranged from 37 to 40 weeks.

Any mother with hypertension or any condition complicating pregnancy-such as diabetes, urinary tract infection, multiple pregnancies, or antepartum haemorrhage-was excluded. All infants were born by normal vaginal delivery and their 1-minute Apgar score was 9 or 10 . No external malformation or other obvious abnormality was found when each infant was examined. Even in the absence of clinical suspicion of intrauterine infection, such an infection cannot be positively excluded, although none of the low birthweight infants had malarial parasites in the thick smear of his peripheral blood. Gestational age of each infant was assessed within 8 hours of delivery using the physical and neurological scales of maturation suggested by Dubowitz et al. ${ }^{9}$

The various anthropometric and clinical data for the 3 groups of mothers and infants are summarised (Table 1). At delivery the umbilical cord was cleaned carefully before about $10 \mathrm{ml}$ whole cord blood was collected. Immediately after delivery $5 \mathrm{ml}$ venous blood was taken from the cubital vein of the

Table 1 Anthropometric and clinical data (mean \pm $S D$ ) of 54 term $A G A, 14$ preterm $A G A$, and $21 S F D$ infants and their mothers. Number of determinations in parentheses

\begin{tabular}{llll}
\hline Data & Term $A G A$ & Preterm AGA & SFD \\
\hline Mothers & & & \\
Age (years) & $24 \cdot 2 \pm 4 \cdot 5$ & $21 \cdot 8 \pm 4 \cdot 8$ & $21 \cdot 3 \pm 4 \cdot 7$ \\
Parity & $(52)$ & $(13)$ & $(19)$ \\
& $3 \cdot 5 \pm 1 \cdot 9$ & $1 \cdot 8 \pm 1 \cdot 1$ & $2 \cdot 5 \pm 2 \cdot 2$ \\
Height (cm) & $(51)$ & $(14)$ & $(21)$ \\
& $153 \cdot 5 \pm 7 \cdot 1$ & $153 \cdot 0 \pm 3 \cdot 0$ & $152 \cdot 5 \pm 4 \cdot 9$ \\
Arm circumference & $(50)$ & $(14)$ & $(19)$ \\
$\quad(\mathrm{cm})$ & $(51) \pm 2 \cdot 6$ & $25 \cdot 2 \pm 2 \cdot 3$ & $24 \cdot 3 \pm 1 \cdot 9$ \\
Infants & & $(12)$ & $(16)$ \\
Ratio (boys: girls) & $26: 28$ & $6: 8$ & $10: 11$ \\
Birthweight (g) & $3036 \pm 262$ & $2035 \pm 500$ & $1553 \pm 476$ \\
& $(54)$ & $(14)$ & $(21)$ \\
Length (cm) & $48 \cdot 5 \pm 1 \cdot 7$ & $44 \cdot 2 \pm 3 \cdot 0$ & $42 \cdot 8 \pm 4 \cdot 0$ \\
& $(54)$ & $(14)$ & $(21)$ \\
Head circumference & $34 \cdot 4 \pm 1 \cdot 0$ & $31 \cdot 3 \pm 2 \cdot 1$ & $30 \cdot 4 \pm 1 \cdot 6$ \\
$\quad(\mathrm{~cm})$ & $(54)$ & $(14)$ & $(21)$ \\
Gestational age & $40 \cdot 1 \pm 0 \cdot 6$ & $35 \cdot 0 \pm 1 \cdot 9$ & $37 \cdot 7 \pm 2 \cdot 1$ \\
$\quad($ weeks) & $(54)$ & $(14)$ & $(21)$ \\
\hline
\end{tabular}


mother. Consent was obtained from each mother. After sampling serum was separated by centrifugation and was stored and transported at $-20^{\circ} \mathrm{C}$ until analysed. The samples were analysed within 3 months of collection. Serum protein was analysed by the Biuret reaction. IgA, IgG, and IgM levels were measured by single radial immunodiffusion, ${ }^{10}$ using commercial rabbit antisera to human IgG, IgM, and $\operatorname{IgA}$, and their specific standards (Behringwerke). Because low concentrations for IgA and IgM were expected in cord blood, low-concentration radial immunodiffusion techniques were used. Electrophoresis of serum proteins was performed on cellulose acetate strips using the Beckman microzone electrophoresis equipment and the Beckman densitometer (R-110).

All laboratory investigations were checked by the laboratories of Sophia Children's Hospital, Rotterdam, by the same methods. The correlation coefficient ( $r$ ) of the investigations performed in Dar-es-Salaam and those in Rotterdam was 0.9 or better. Significance of differences between means were measured by Student's $t$ test.

\section{Results}

Maternal blood tests. Mean serum concentration ( \pm SD) of total protein, immunoglobulins (IgG, IgM, and IgA) for mothers of term AGA, preterm AGA, and SFD infants are shown in Table 2. Total protein, IgG, IgM, and IgA showed a nearly symmetrical distribution in all three, except for IgM in mothers of SFD infants. Higher levels of total protein were found in mothers of preterm AGA and SFD infants compared with mothers of term AGA infants $(P<0.001$ and $P<0.05$ respectively). In mothers of term AGA infants $42 \%$ of the total protein concentration $(6 \cdot 8 \mathrm{~g} / 100 \mathrm{ml})$ was albumin $(2 \cdot 9$ $\mathrm{g} / 100 \mathrm{ml})$, and $20 \%$ was $\gamma$-globulin $(1.4 \mathrm{~g} / 100 \mathrm{ml})$. IgG levels were slightly higher in mothers of preterm AGA than in mothers of term AGA and SFD infants. In mothers of SFD infants, higher values of
$\operatorname{IgA}(\mathrm{P}<0.01)$ and $\operatorname{IgM}$ were found than in mothers delivering term AGA infants. No noticeable changes in maternal IgG were observed during the last 8 weeks of pregnancy as calculated by multiple regression analysis $(r=0 \cdot 246)$.

Cord blood tests. Total proteins and IgG levels showed a nearly symmetrical distribution in the 3 groups of infants, whereas for IgM and IgA a nearly normal distribution was obtained after logarithmic transformation of the values. Mean serum concentration $( \pm$ SD) of total protein and immunoglobulins (IgG, IgM, and IgA) in term AGA, preterm AGA, and SFD infants in cord blood are shown in Table 2. In term AGA infants the mean serum total protein was $6.9 \pm 0.5 \mathrm{~g} / 100 \mathrm{ml}$. This was slightly higher than that in preterm AGA or SFD infants $(P<0.05)$. In this group of infants, albumin accounted for $60 \%$ and $\gamma$-globulins for $20 \%$ of the total protein values $(4 \cdot 1 \pm 0.2$ and $1.4 \pm 0.2 \mathrm{~g} / 100 \mathrm{ml}$ respectively). No differences were found in the mean levels of immunoglobulins $\operatorname{IgG}, \operatorname{IgM}$, and $\operatorname{IgA}$ in the 3 groups of newborn babies. The IgM was $>20 \mathrm{mg} / 100 \mathrm{ml}$ at birth in $40 \%$ of the SFD, in $25 \%$ of the preterm AGA, and in $14 \%$ of the term AGA infants. Individual values of serum IgG, IgM, and IgA from cord blood of term AGA, preterm AGA, and SFD babies are plotted against gestational age in Fig. 2. IgM was detectable in the 31 st week of gestation, whereas IgA levels were not detected until the 35th week of gestation.

In normal term infants, mean IgG in cord serum was higher in children of primiparous than of multiparous mothers $(1723 \mathrm{v} .1327 \mathrm{mg} / 100 \mathrm{ml})$. This difference was not observed for IgA or IgM. In this group of infants IgM was detectable in all the cord sera. In $13(27 \%)$ of the term AGA children, IgM values were $20 \mathrm{mg} / 100 \mathrm{ml}$ or more. Among this group of infants, mean birthweight was slightly higher compared with mean birthweight of the whole group, but not significantly so. The mean $\operatorname{IgA}$ level in the term AGA infants was $5.5 \mathrm{mg} / 100 \mathrm{ml}$. In $17(35 \%)$

Table 2 Total protein, IgG, IgM, and IgA of maternal/cord serum pairs in 54 term AGA, 14 preterm AGA, and 21 $S F D$ infants and their mothers (mean $\pm S D$ ). Number of determinations in parentheses

\begin{tabular}{|c|c|c|c|c|c|c|}
\hline \multirow[t]{2}{*}{ Data } & \multicolumn{3}{|l|}{ Mothers } & \multicolumn{3}{|l|}{ Babies } \\
\hline & Term $A G A$ & Preterm $A G A$ & $S F D$ & Term $A G A$ & Preterm $A G A$ & $S F D$ \\
\hline $\begin{array}{l}\text { Total protein } \\
(\mathrm{g} / 100 \mathrm{ml})\end{array}$ & $\begin{array}{l}6.8 \pm 0.8 a * b * * * \\
(49)\end{array}$ & $7 \cdot 8 \pm 0.6(14)$ & $7 \cdot 5 \pm 0 \cdot 9(18)$ & $\begin{array}{l}6 \cdot 9 \pm 0.5 c * * * d * * * * \\
\quad(49)\end{array}$ & $6 \cdot 3 \pm 0 \cdot 7$ & $6 \cdot 2 \pm 1 \cdot 0$ \\
\hline $\begin{array}{l}\text { IgG }(\mathrm{mg} / 100 \mathrm{ml}) \\
\operatorname{IgM}(\mathrm{mg} / 100 \mathrm{ml}) \\
\text { IgA }(\mathrm{mg} / 100 \mathrm{ml})\end{array}$ & $\begin{array}{l}1840 \pm 419(49) \\
155 \pm 51(49) \\
152 \pm 78 \text { b** (49) }\end{array}$ & $\begin{array}{c}2059 \pm 530(14) \\
180 \pm 57(14) \\
177 \pm 79(14)\end{array}$ & $\begin{array}{c}1918 \pm 539(19) \\
254 \pm 227(18) \\
216 \pm 95(19)\end{array}$ & $\begin{array}{l}1471 \pm 304(49) \\
15 \cdot 3 \pm 9(49) \\
5 \cdot 5 \pm 5 \cdot 8(49)\end{array}$ & $\begin{array}{l}1398 \pm 442(14) \\
28 \cdot 8 \pm 24 \cdot 6(14) \\
2 \cdot 8 \pm 6(14)\end{array}$ & $\begin{array}{c}1505 \pm 361(16) \\
20 \cdot 4 \pm 17 \cdot 3(16) \\
5 \cdot 6 \pm 4 \cdot 9(16)\end{array}$ \\
\hline
\end{tabular}

*Difference between means $P<0.001, * *$ difference between means $P<0.01$, ***difference between means $P<0.05$.

$a=$ Comparison of values between mothers of term and preterm infants, $b=$ comparison of values between mothers of term and SFD infants, $c=$ comparison of values between term and preterm infants, $d=$ comparison of values between term and SFD infants.

Conversion: traditional to SI units-total protein, IgG, IgM, and IgA $1 \mathrm{mg} / 100 \mathrm{ml} \approx 0.01 \mathrm{~g} / 1$. 


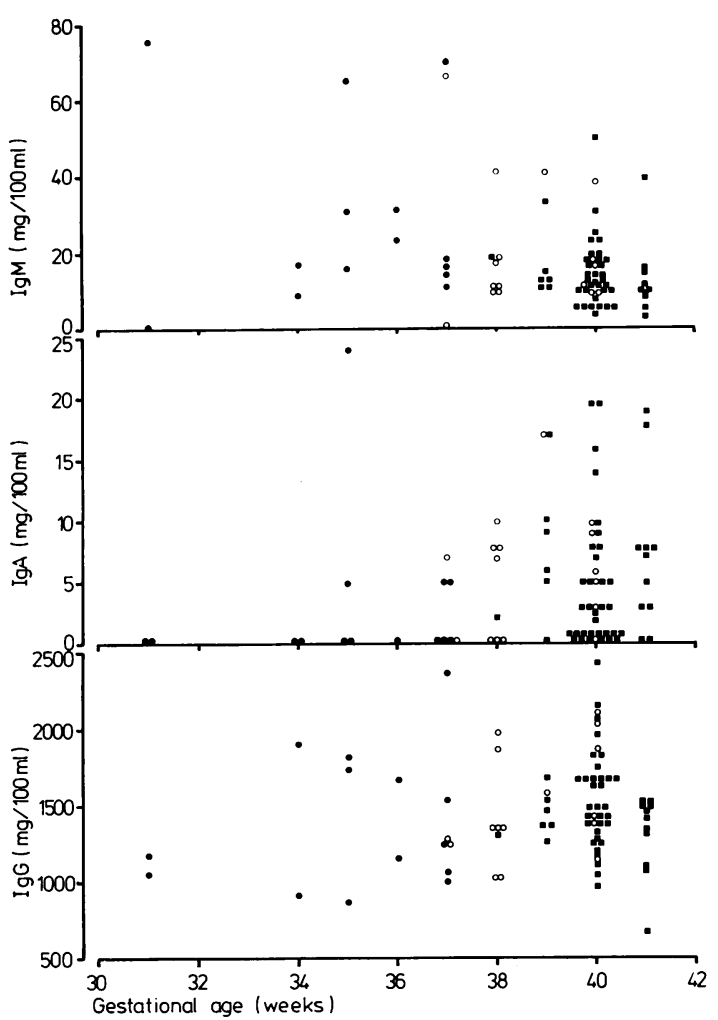

Fig. 2 Individual values for serum $\operatorname{Ig} M, \operatorname{Ig} A$, and IgG in cord blood of preterm AGA ( $), S F D(0)$, and term AGA infants ( $\square)$ plotted against gestational age.

of these infants $\operatorname{IgA}$ could not be detected in cord serum.

Maternal/fetal blood ratios. The mean concentration of IgG in the mother was 1.25 times greater than in her child in the term AGA group, 1.47 times greater $\mathrm{n}$ the mothers of preterm AGA, and 1.27 times greater in the mothers of SFD babies. Generally higher values of $\mathrm{IgG}$ in the mother corresponded to higher values in the fetus.

\section{Discussion}

Two assumptions were made in an attempt to relate the levels of IgG, IgM, and IgA in maternal and cord blood in Tanzania with those of other studies in Western countries. Firstly, it was assumed that the immunoglobulin levels in preterm AGA infants and their mothers reflected the normal events during pregnancy. Secondly, it was assumed that the methods used would justify comparison with other studies. Regarding the first assumption it should be remembered that the term 'preterm appropriate-forgestational-age' is in a sense paradoxical, as events leading to or accompanying preterm birth must be 'abnormal' and may well affect the relative proportions of some components in the mother or her fetus. However the same criteria were used by studies in Western countries. The last assumption is probably valid since the low concentration radial immunodiffusion techniques were used for the IgA and IgM determinations in cord blood, with a detection limit of $1 \mathrm{mg} / 100 \mathrm{ml}$ for IgM.

In this study, among mothers delivering a term AGA infant, the mean value for total protein $(6.8 \mathrm{~g} / 100 \mathrm{ml})$ and albumin $(2.9 \mathrm{~g} / 100 \mathrm{ml})$ was higher than found in white women. ${ }^{11-15}$ Our range of means was 5.9-6.4 for total protein and 2.4 $2.75 \mathrm{~g} / 100 \mathrm{ml}$ for albumin. Somewhat higher values for total protein $(7 \cdot 2-8 \cdot 0 \mathrm{~g} / 100 \mathrm{ml})$ were found in well-nourished African, Hindu, and Bantu women towards the end of pregnancy. ${ }^{16-17}$ Mean IgG values at the end of normal pregnancy $(1840 \mathrm{mg} / 100 \mathrm{ml})$ were higher than is normal for white women (1000-1400 mg as reviewed by de Muralt ${ }^{18}$ ), whereas IgA and IgM levels were similar. This was found also in another study in Africa. ${ }^{19}$ The reason for the higher IgM and IgA levels among mothers of SFD infants remains unclear, although it might be explained by a higher incidence of (subclinical) infections.

In the group of Tanzanian term AGA infants we studied, mean total protein level was higher than that reported in infants from Western countries (average $5.8 \mathrm{~g} / 100 \mathrm{ml}$, Schultze and Heremans ${ }^{20}$ ), which may partly be explained by the higher albumin levels, $4 \cdot 1$ v. $3 \cdot 5-4 \cdot 0 \mathrm{~g} / 100 \mathrm{ml}$, in Western term infants. ${ }^{18}$

When the individual values in the three groups of Tanzanian infants in relation to their gestational age (Fig. 1) were compared with studies in the USA ${ }^{21}$ the de novo synthesis of IgM and IgA by the fetus seems to be activated at an earlier gestational age. This assumption is further substantiated by the higher incidence of detectable IgM $(100 \%)$ and especially of IgA levels $(65 \%)$ in the term AGA infant at birth compared with the infant in Western countries (75\% for IgM, and $0-30 \%$ for IgA as reviewed by de Muralt ${ }^{18}$ ).

Since the fetus synthesises most of its proteins, with the exception of IgG, from amino-acids which have been transferred across the placenta ${ }^{22}$ it can be assumed that the rate of synthesis of albumin, IgM, and IgA by the Tanzanian fetus is greater than that found in Western countries during the last stage of pregnancy. The high endogenous synthesis of IgM and IgA in the fetus might be explained by increased 
induction from antigenic stimuli in the maternal environment, although a genetic origin cannot be excluded. It was beyond the scope of this study to evaluate the incidence of intrauterine infection among the infants, although it can be said that none of the infants in the low birthweight groups, and only one infant in the term AGA group had malarial parasites in the cord blood smear at birth. In this particular infant, IgM level was $20 \mathrm{mg} / 100 \mathrm{ml}$; the child was clinically well and went home without any treatment: at the postnatal follow-up no abnormalities were noted. Among the preterm AGA infants all were discharged home in good condition, except one with a gestational age of 31 weeks who died at age 3 weeks, severely dehydrated. In the SFD group all were discharged home in good condition.

No attempts were made to evaluate the cellular immunity in this community of mothers and infants.

In conclusion, in paired Tanzanian maternal/fetal blood, generally higher values were detected for total protein, albumin, and IgG in maternal blood at the end of pregnancy, compared with Western standards. The concentration of total protein, albumin, and IgG in the fetal circulation was also increased compared with the same standards, with a higher detection rate for IgM and IgA, which could be explained by an increased induction of the fetal humoral antibody synthesis from antigenic stimuli in the maternal environment. Contrary to findings in Western countries, IgG in the maternal sera tended to be higher than in the corresponding fetal circulation.

I thank Mr Henk Visser, Mrs Petra Visser, Mr L Baars, Dr E Ben Gershôn and his staff, and the nursing staff of the maternity ward in Muhimbili Medical Centre, for help, and Professor J H P Jonxis, Professor H K A Visser, and Dr R G Pearse for help and constructive criticism.

This study was supported by a grant from the Foundation De Drie Lichten.

\section{References}

1 Mbise R L, Boersma E R. Factors associated with low birth weight in the population of Dar-es-Salaam, Tanzania. Trop Geogra Med 1979; 31 : 21-32.

2 Chandra R K. Fetal malnutrition and postnatal immunocompetence. Am J Dis Child 1975; 129: 450-4.

3 Sever J L, Ellenberg J, Gilkson M R. Infection and low birth weight in an industrialized society. Am J Dis Child 1975; 129: 557-8.
4 Peel E, van Hoof L. La paludisme à la maternité indigène de Leopoldville. Ann Soc Belg Med Trop 1948; 28: 413-20.

5 Garnham P C C. Malarial immunity in Africans: effects in infancy and early childhood. Ann Trop Med Parasitol 1949; 43: 47-59.

6 Bruce-Chwatt L J. Malaria in African infants and children in Southern Nigeria. Ann Trop Med Parasitol 1952; 46: 173-200.

7 Kortman H F. Malaria and pregnancy. MD thesis, Drukkerij Elinkwijk 1972.

8 Boersma E R, Mbise R L. Intrauterine growth of liveborn Tanzanian infants. Trop Geogra Med 1979; 31 : 7-20.

9 Dubowitz L M B, Dubowitz V, Goldburg C. Clinical assessment of gestational age in the newborn infant. J Pediatr 1970; 77: 1-10.

10 Mancini G, Vaerman J P, Carbonara A O, Heremans J F. A single radial diffusion method for the immunological quantitation of proteins. Protides Biol Fluids 1964; 11: 370-9.

11 de Alvarez R R, Afonso J F, Sherrard D J. Serum protein fractionation in normal pregnancy. Am J Obstet Gynecol 1961; 82: 1096-111.

12 Robertson E G. The natural history and physiology of oedema occurring during pregnancy. MD thesis, University of Newcastle upon Tyne 1970.

13 Hytten F E, Leitch I. The physiology of human pregnancy, second edition. Oxford: Blackwell, 1971.

14 Morse E H, Clarke R P, Keyser D E, Merrow S B, Bee D E. Comparison of the nutritional status of pregnant adolescents with adult pregnant women. I. Biochemical findings. Am J Clin Nutri 1975; 28: 1000-13.

15 Reboud P, Groslambert P, Ollivier C, Groulade J. Protéines et lipides plasmatiques au cours de la gestation normale et du post-partum. Ann Biol Clin (Paris) 1967; 25: $383-403$.

16 Sénécal J, Berton M. Étude comparative des protéines seriques de la mére, de l'enfant et du cordon à la maternité Africaine de Dakar consideration sur la transmission des gammaglobulines. Bull Médicale AOF 1957; 2: 303-10.

17 Plagnol H. Protidémie et syphilis chez les mères et nouveaunés Africains à Dakar. Bull Médicale AOF 1958; 3: 399-414.

18 de Muralt G. Maturation of cellular and humoral immunity. In: Stave U, ed. Perinatal physiology. New York: Plenum, 1978; 267-305.

19 McFarlane H, Udeozo O K. Immunochemical estimation of some proteins in Nigerian paired maternal and fetal blood. Arch Dis Child 1968; 43: 42-6.

20 Schultze H E, Heremans J F. Molecular biology of human proteins. Vol. 1. Amsterdam: Elsevier, 1966.

21 Stiehm E R. Fetal defense mechanisms. Am J Dis Child 1975 ; 129 : 438-43.

22 Gitlin D, Gitlin J D. Protein transfer across the placenta. In: Putnam F W, ed. The plasma proteins. New York: Academic Press, 1975: 264-317.

Correspondence to Dr E R Boersma, University of the West Indies, Department of Child Health, Mona, Kingston 7, Jamaica, West Indies.

Received 30 August 1979 